\title{
JOURNAL.RU
}

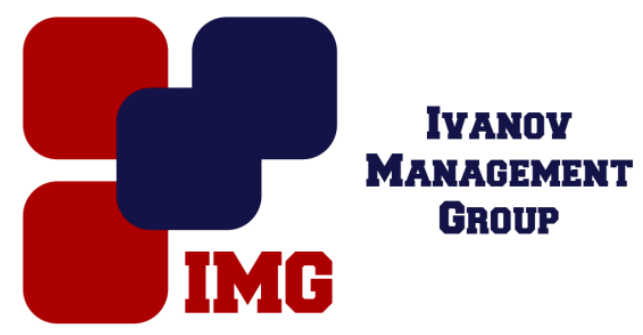

Артемов В.А.

Российский университет дружбы народов Москва, Россия

doi: $10.18411 / 1 \mathrm{j}-30-06-2017-28$

idsp 000001:1j-30-06-2017-28

\section{Практика Конституционного Суда РФ и Верховного Суда РФ по спорам о защите деловой репутации}

\section{Аннотация}

В статье рассмотрено понятие деловой репутации, а также основные практические сложности в решение споров о защите деловой репутации, практика Верховного Суда РФ и Конституционного Суда РФ по рассмотрению данных споров.

Ключевые слова: защита деловой репутации, деловая репутация, нематериальные блага, судебная практика, обзор практике по деловой репутации.

\section{Annotation}

The article considers the notion of business reputation, as well as the main practical difficulties in resolving disputes on the protection of business reputation, the practice of the Supreme Court of the Russian Federation and the Constitutional Court of the Russian Federation to review these disputes.

Key words: protection of business reputation, business reputation, intangible benefits, judicial practice, review of business reputation practice.

В соответствии с ГК РФ, защите подлежат не только материальные права, но и нематериальные блага каждого человека. К таким благам относится деловая репутация. Подобные положения, связанные с защитой деловой репутации, существуют практически во всех государствах мира, в том числе и в странах 
Азии с принципиально иной правовой и политической системой. Как отмечает А.А. Солоненко, законодательно не утверждена методика оценки деловой репутации, а также методика определения ее справедливой стоимости. В то же время, сама деловая репутация представляет собой вид неотчуждаемого и непередаваемого нематериального блага, принадлежащего физическому или юридическому лицу с точки зрения его деловых качеств.

Важно отметить, что субъектами деловой репутации могут быть не все физические лица. Как справедливо указывает А.Р. Гусалова, представляется, что деловой репутацией могут обладать далеко не все субъекты гражданского права, а лишь лица, осуществляющие социально значимую деятельность. Не могут иметь деловой репутации неработающие пенсионеры, инвалиды, не имеющие физической возможности заниматься каким-либо делом, домохозяйки. В то же время, понятие деловой репутации не следует толковать излишне узко и отождествлять с предпринимательской репутацией, так как деловую репутацию также могут иметь чиновники, адвокаты, профессионалы высокого уровня в различных профессиях и т.д.

Так как деловая репутация является нематериальным благом, каждое лицо, считающее, что его деловая репутация была повреждена незаконными действиями других лиц имеет право потребовать восстановления своих прав, используя методы гражданско-правовой защиты деловой репутации. При этом, как справедливо указывает Е.П. Ермакова, необходимо различать способы защиты права в материальном смысле (ст. 12 ГК РФ) и способы разрешения споров в процессуальном смысле. Основной материальной формой защиты по данной категории дел является опровержение недостоверной информации.

Важнейшую роль в формировании правильного подхода к рассмотрению споров о защите деловой репутации играет судебная практика Верховного Суда РФ, являющегося высшим судом в системе судов Российской Федерации, также Конституционного Суда РФ.

Так, статьей 152 ГК РФ установлены пределы возможной защиты деловой репутации, а также пределы возможных способов защиты деловой репутации. Так п. 17 Обзора практики рассмотрения судами дел по спорам о защите чести, достоинства и деловой репутации установлено, что не могут рассматриваться как не соответствующие действительности сведения, содержащиеся в процессуальных документах, для обжалования которых предусмотрен иной установленный законом судебный порядок. 
Таким образом, если, по мнению заинтересованного лица, не соответствующие действительности сведения находятся в материалах дела, то оценку соответствия или не соответствия действительности таким сведениями дает именно соответствующий суд, рассматривающий дело по сути. С таким решением согласился КС РФ в своем Определении от 20.04.2017 г., признав отсутствие нарушения конституционных прав граждан на защиту.

Важно отметить, что деловая репутация, защищаемая в порядке арбитражного судопроизводства, относится к сфере предпринимательской или иной экономической деятельности. В том случае, если защита нематериальных прав осуществляется в связи с их нарушением, не связанным со сферой предпринимательской или иной экономической деятельности, такой иск подведомственен не арбитражным судам, а судам общей юрисдикции. При этом, тот факт, что лицо является предпринимателем не является сам по себе основанием для рассмотрения дела в порядке арбитражного судопроизводства.

Довольно серьезной проблемой при рассмотрении дела, связанного с защитой деловой репутации, является размежевание распространения сведений, порочащих деловую репутацию с субъективным мнением автора. Таким образом, в данном случае вступают в конфликт два права: право на свободу слова и право на защиту от недостоверных сведений, порочащих честь, достоинство и деловую репутацию. Верховный Суд РФ в своем определении от 10.04.2017 указал, что необходимо четко различать факты и оценки фактов. Любые факты могут быть проверяемы на предмет достоверности и распространение недостоверной информации влечет за собой возможность лица, которого касается эта недостоверная информация, защитить свою деловую репутацию. В то же время, оценка фактов является субъективным критерием и каждый человек имеет право, не допуская прямых оскорблений или обвинений в совершении преступлений, интерпретировать факты таким образом, каким считает нужным.

Также нужно учитывать, что жанровые особенности статьи сами по себе не могут считаться достаточным основанием для выдачи субъективного мнения за объективный недостоверный факт и в таком случае имеет место быть распространение недостоверных сведений, наносящих ущерб деловой репутации.

Обязанность доказывания достоверности распространяемых сведений лежит на ответчике. При этом, ответчик должен доказывать эти сведения в соответствии с правилами судопроизводства, на основании допустимых и 
надлежащих доказательств. Таким образом, если достоверность сведений подтверждается исключительно ненадлежащими доказательствами, такие сведения не могут быть признаны достоверными. Так в одном из своих решений ВС РФ установил, что как факт достоверности опубликованных сведений не доказан, поскольку ответчиком-2 нарушен порядок отбора проб бензина; суды не дали оценки представленному истцом экспертному лингвистическому исследованию и пришли к ошибочному выводу о том, что оспариваемые сведения являются выражением субъективного мнения их автора.

Как видим, несмотря на значительную судебную практику ВС РФ, в судах низших инстанций регулярно возникают сложности с разграничением фактической информации, которую можно проверить на достоверность и субъективным мнением автора. Очевидно, что подобная ситуация часто приводит к неправомерным решениям судов, в последствие обжалуемых в апелляционном и кассационном порядке. Сложности устранения подобных противоречий состоят в практической неисчерпаемости языковых ресурсов и их использования автором. По нашему мнению, судья должен в каждом конкретном случае разбирать, имеет ли место быть утверждение о факте или субъективное мнение автора. При объективных сложностях такого установления, суд должен назначить соответствующую лингвистическую экспертизу, заслушать показания специалистов и воспользоваться другими предусмотренными процессуальным законодательством способами для выяснения истины по делу. 
1. Гражданский процесс и гражданское законодательство в странах АзиатскоТихоокеанского региона: монография/В.В.Безбах, К.М.Беликова, Н.В.Бадаева (и др.) Москва, РУДН, 2015, - 345 с. ISBN 978-5-209-06946-1.

2. Солоненко Анна Александровна, Петровская Галина Александровна Понятие, виды, методы оценки и учет деловой репутации // Вестник АГТУ. Серия: Экономика. 2014. №2. C.110-119

3. Гусалова Анжела Руслановна Гражданско-правовая защита деловой репутации // Бизнес в законе. 2010. №2. С.68-70

4. Ермакова Е.П. К вопросу о понятии форм и способов разрешения споров в разносистемных правопорядках// Пробелы в российском законодательстве - М., 2016, номер 6, с. 55-58

5. "Обзор практики рассмотрения судами дел по спорам о защите чести, достоинства и деловой репутации" (утв. Президиумом Верховного Суда РФ 16.03.2016) [Электронный ресурс] режим доступа: http://www.consultant.ru/document/cons_doc_LAW_195322/

6. Определение Конституционного Суда РФ от 20.04.2017 N 867-O

7. "Об отказе в принятии к рассмотрению жалобы гражданина Латыпова Марата Камилевича на нарушение его конституционных прав положениями статьи 152 Гражданского кодекса Российской Федерации"

8. Определение Верховного Суда РФ от 16.11.2015 N 305-ЭС15-13898 по делу N А40$87646 / 2013$

9. Определение Верховного Суда РФ от 10.04.2017 N 309-ЭС16-20725 по делу N А60$60524 / 2015$

10. Определение Верховного Суда РФ от 16.12.2016 N 309-ЭС16-10730 по делу N А07$12906 / 2015$

11. Определение Верховного Суда РФ от 07.12.2016 N 310-ЭС16-10931 по делу N А68$7214 / 2015$ 